\title{
Media Video Edukasi untuk Meningkatkan Efikasi Diri Anak Tuna Grahita
}

\author{
Romia Hari Susanti \\ Universitas PGRI Kanjuruhan - Malang, 65148, Indonesia \\ E-mail: romi@unikama.ac.id. No. HP +6285735879100
}

Received: 30 Agustus 2021; Revision: 23 September 2021; Accepted: 29 Oktober 2021

\begin{abstract}
Abstrak
Anak berkebutuhan khusus dengan segala keterbatasannya memiliki kesulitan saat mengikuti pembelajaran. Melalui efikasi diri diharapkan keterbatasan yang menjadi penghalang proses belajar akan mudah dilalui oleh siswa berkebutuhan khusus. Efikasi diri sebagai suatu kompetensi memilki empat dimensi meliputi kognitif, motivasi, afeksi, dan seleksi yang akan mendorong individu untuk berusaha mengatasi hambatan. Dalam upaya membimbing anak tunagrahita menjadi pribadi yang mandiri, penggunaan video edukasi dapat digunakan secara individual, tidak hanya dalam setting sekolah, tetapi juga bisa diputar ulang di rumah melalui panduan dari guru atau cukup mendengarkan uraian narasi dari narator yang telah terekam. Melalui video anak langsung mendapat umpan balik secara visual terhadap kemampuan mereka sehingga mampu mencoba keterampilaan yang diharapkan terbentuk. Video edukasi dirancang sebagai media yang menyajikan audio dan visual berisi pesan dan serangkaian gambar yang menunjukkan contoh cara bersikap dan keterampilan tertentu sebagai bentuk layanan bantuan yang diberikan kepada individu dalam rangka membahas beberapa permasalahan yang sedang terjadi.
\end{abstract}

Kata Kunci: Tuna grahita; Video edukasi; Efikasi Diri

\begin{abstract}
Children with special needs with all their limitations have difficulties when participating in learning. Through self-efficacy, it is hoped that the limitations that hinder the learning process will be easily passed by students with special needs. Self-efficacy as a competency has four dimensions including cognitive, motivation, affection, and selection that will encourage individuals to try to overcome obstacles. In an effort to guide mentally retarded children to become independent individuals, the use of educational videos can be used individually, not only in a school setting, but also can be played back at home through guidance from the teacher or simply listen to the recorded narrative description from the narrator. Through videos, children immediately get visual feedback on their abilities so that they are able to try the skills that are expected to be formed. Educational videos are designed as media that present audio and visual messages and a series of pictures that show examples of how to behave and certain skills as a form of assistance services provided to individuals in order to discuss some of the problems that are happening.
\end{abstract}

Key Word: Mental retardation; Educational video; Self Efficacy

Susanti, R. (2021). Media Video Edukasi untuk Meningkatkan Efikasi Diri Anak Tuna Grahita. Masyarakat Berdaya dan Inovasi, 2(2), 104 - 111. doi:https://doi.org/10.33292/mayadani.v2i2.71 


\section{PENDAHULUAN}

Efikasi diri adalah keyakinan tentang kemampuan seseorang untuk mengatur dan menjalankan program tindakan yang diperlukan untuk menghasilkan pencapaian yang diinginkan (Bandura, 2002). Makna yang terkandung di dalamnya adalah efikasi diri merupakan kemampuan kognitif yang dapat dijadikan sebagai perantara perubahan perilaku. Menurut sumber lain yang mengutip Bandura menyatakan bahwa keyakinan manusia mengenai efikasi diri mempengaruhi bentuk tindakan yang akan mereka pilih untuk dilakukan, sebanyak apa usaha yang akan mereka berikan ke dalam aktivitas ini, selama apa mereka akan bertahan dalam menghadapi rintangan dan kegagalan, serta ketangguhan mereka mengikuti adanya kemunduran (Roberts, 2007). Selanjutnya Pajares (2002) mendefinisikan efikasi diri adalah persepsi bahwa seseorang mampu melakukan sesuatu yang penting untuk mencapai tujuannya.

Adapun fungsi efikasi diri antara lain: 1) seseorang yang mempunyai efikasi diri yang kuat cenderung akan lebih meningkatkan prestasinya dengan banyak cara (lebih kreatif dalam bertindak); 2) tugas yang sulit akan mereka anggap sebagai tantangan untuk dikuasai bukan sebagai ancaman yang harus dihindari; 3) mereka mengatur diri mereka untuk sebuah tujuan yang menantang tersebut dan mempertahankan komitmen mereka untuk dapat mewujudkan hal tersebut; 4) mereka meningkatkan dan mempertahankan usaha mereka dalam menghadapi kegagalan; 5) mereka dengan cepat memulihkan kembali semangat pada diri mereka setelah mengalami kegagalan atau kemunduran; 6) mereka senantiasa dapat mengontrol dirinya dan dapat mengahasilkan prestasi diri yang baik, mengurangi stres serta dapat menurunkan kerentanan tehadap depresi (Bandura, 2002). Jadi dapat disimpulkan jika siswa mempunyai efikasi diri yang kuat, maka pemikiran ragu atau kurang yakin pada diri siswa apakah siswa dapat berhasil untuk memenuhi standar tersebut atau tidak, dan mempunyai harapan keberhasilan yang rendah tersebut dapat diminimalisir.

Menurut Bandura (2002) efikasi diri memiliki perbedaan yang variatif pada setiap dimensi. Perbedaan yang variatif berimplikasi pada pelaksanaan tugas atau pekerjaan. Bandura menyebutkan tiga dimensi efikasi diri yaitu: a) dimensi tingkat (level), b) dimensi umum, dan c) dimensi kekuatan (strength). Individu yang memiliki efikasi diri rendah, tidak memiliki keyakinan untuk membuat suatu keputusan, sehingga berusaha untuk menghindari tugas tersebut. Sebaliknya, individu yang memiliki efikasi diri, mempunyai dorongan untuk berusaha mengatasi hambatan, mencari informasi yang lebih luas.

Menurut Nursalim (2005), model belajar sosial yang mengacu pada teori Bandura (2002) menunjukkan jenis dan kualitas efikasi diri pada diri seseorang terbentuk, berubah dan berkembang karena hasil belajar melalui salah satu atau kombinasi dari empat sumber utama, yaitu: (1) performance accomplishment atau pengalaman yang berhubungan dengan kesuksesan dan kegagalan dari pencapaian hasil yang diharapkan, (2) vicarious learning, yaitu hasil pengamatan dari perilaku orang lain. Pengalaman keberhasilan orang lain yang memiliki kemiripan dengan individu dalam 
mengerjakan suatu tugas biasanya akan meningkatkan efikasi diri seseorang dalam mengerjakan tugas yang sama, (3) emotional arousal, yaitu keadaan emosi dalam menghadapi situasi yang penuh tantangan dan hambatan. Emotional arousal terkait dengan tinggi rendahnya efikasi diri.

Variabel prediktif tersebut: 1) efikasi diri yang tinggi jika didukung dengan lingkungan yang responsif, hasilnya kemungkinan besar tercapai; 2) efikasi diri yang rendah didukung dengan lingkungan yang responsif, seseorang mungkin akan mengalami kesulitan untuk menyelesaikan tugas yang dia sendiri merasa tidak mampu dan dihadapkan pula dengan keberhasilan orang lain; 3) efikasi diri yang tinggi dan dihadapkan dengan lingkungan yang tidak responsif, biasanya seseorang itu akan meningkatkan usahanya untuk mengubah lingkungan; 4) efikasi diri yang rendah dan dihadapkan dengan lingkungan yang tidak responsif, maka seseorang tersebut akan merasa tidak berdaya (Feist, 2011). Hal ini sesuai dengan hasil penelitian Hudaiyah (2016) yang menyimpulkan adanya pemberian motivasi melalui persuasi positif kepada anak-anak berkebutuhan khusus dalam mengarahkan minat dan bakat mereka sebagai bentuk dukungan lingkungan yang responsif membuat anak-anak menjadi tangguh dan tidak terlalu fokus dengan kekurangan yang dimiliki. Sehingga melalui kegiatan pengabdian ini diharapkan mampu mewujudkan lingkungan positif yang memfasilitasi pengembangan self efikasi diri anak berkebutuhan khusus dengan pemberian stimulus berbantuan media video edukasi.

SLB Raharja Sejahtera merupakan guru pembimbing khususan luar biasa yang menaungi anak-anak dengan kondisi berkebutuhan khusus untuk memberikan guru pembimbing khususan yang layak kepada mereka. Seluruh guru pembimbing khusus di SLB Raharja Sejahtera berharap agar anakanak yang mereka bina mampu berkembang secara optimal. Menurut Effendi (2006) definisi anak berkebutuhan khusus adalah anak dengan karakteristik khusus dan berbeda dengan anak pada umumnya tanpa selalu menunjukkan pada ketidakmampuan mental, emosi, dan fisik. Berdasarkan beberapa keterbatasan yang dimiliki ada kondisi yang menunjukkan kelemahan dari segi inteligensi yang digolongkan dalam kelompok tuna grahita. Keterbatasan inteligensi, bahasa dan kemampuan mental lainnya mengakibatkan anak tuna grahita kurang mampu mempertimbangkan sesuatu, membedakan yang baik dan buruk, sedang dan berat, benar dan salah, sehingga tidak dapat membayangkan konsekuensi dari suatu perbuatan. Dengan guru pembimbing khusus dan keterampilan khusus yang diberikan, seluruh anak tuna grahita diharapkan menjadi individu yang mandiri dan berdaya saing tinggi.

Dalam upaya membimbing anak tuna grahita untuk menjadi pribadi yang mandiri, terdapat beberapa kendala. Salah satu kendala yang dihadapi adalah rendahnya kepercayaan diri anak berkebutuhan khusus terhadap kemampuannya dalam mencapai apa yang diinginkannya yang untuk selanjutnyadi disebut efikasi diri. Salah satu kendala yang dihadapi adalah rendahnya kepercayaan diri anak berkebutuhan khusus terhadap kemampuannya dalam mencapai apa yang diinginkannya yang untuk selanjutnyadi disebut efikasi diri. Dari hasil wawancara pada pertemuan pengabdi dengan anak 
yang memiliki keterbatasan menyandang tuna grahita diperoleh keterangan bahwa mereka merasa tidak yakin akan cita-citanya tercapai. Ketidak yakinan tersebut dipengaruhi oleh kondisi mereka yang kebanyakan memiliki keterbatasan kompetensi baik fisik, mental intelektual, sosial maupun emosionalnya. Mereka merasa tidak yakin dengan apa yang mereka ingin capai karena adanya keterbatasan kompetensi.

Hal serupa juga disampaikan oleh salah satu guru pembimbing khusus di SLB Raharja Sejahtera bahwa anak tuna grahita memiliki masalah yang komplek dalam kehidupannya, pertama mereka mengalami kesulitan melalakukan aktifitas sehari-hari misalkan memasang sepatu, mencuci pakaian, menyiapkan keperluan sekolah, dan sebagainya. Kedua, kesulitan belajar, terutama dalam bidang pengajaran akademik misalnya matematika, IPA dan bahasa. Ketiga, kemampuan penyesuaian diri anak tuna grahita dipengaruhi oleh kecerdasan yang dimiliki bahkan mereka menjadi terisolir karenanya. Keempat, tingkat kemandirian dan cenderung bergantung pada orang lain terutama orang tua (keluarga). Seberapa kuat anak tuna grahita mampu melawan keterbatasan yang mereka miliki dan mandiri dalam menyiapkan keperluan guru pembimbing khusus menjadi hal penting dalam kesiapan kehidupan mereka.

Anak tuna grahita memiliki potensi dalam belajar bergantung berat ringannya ketunagrahitaan yang mereka alami. Sehingga yang diperlukan adalah layanan pembelajaran yang sesuai dengan kebutuhan khusus anak tuna grahita. Mereka membutuhkan layanan seprti program stimulasi dan intervensi, bermain, okupasi, terapi bicara dan kemampuan memelihara diri serta belajar akademik. Masalah ini yang melatar belakangi pengabdian masyarakat ini dilakukan. Penggunaan media video edukasi dinilai efektif untuk meningkatkan efikasi diri anak tuna grahita yayasan raharja sejahtera kandangan kabupaten Kediri. Video edukasi efikasi diri dapat digunakan oleh anak secara individual, tidak hanya dalam setting sekolah, tetapi juga bisa diputar ulang di rumah melalui panduan dari guru atau cukup mendengarkan uraian narasi dari narator yang telah terekam. Melalui video anak langsung mendapat umpan balik secara visual terhadap kemampuan mereka sehingga mampu mencoba keterampilaan yang diharapkan terbentuk. Anak tuna grahita memiliki kelebihan spontanitas wajar yang positif serta kecenderungan merespon orang lain dengan baik, jujur, hangat dan sangat mempercayai hal positif yang diajarkan orang lain. Diharapkan dengan menggunakan media video edukasi efikasi diri anak tuna grahita dapat meningkat.

\section{METODE}

Bantuan stimulasi dan intervensi untuk anak tuna grahita dengan menggunakan bantuan media video edukasi yang dapat digunakan secara individu tidak hanya di sekolah, tetapi juga bisa diputar ulang di rumah melalui panduan dari guru atau cukup mendengarkan narasi yang telah terekam serta dan akan memperoleh umpan balik secara visual untuk keterampilan yang sudah mereka coba. Keterampilan efikasi diri membantu anak tuna grahita dalam menghadapi situasi sulit di sekolah, guna 
menumbuhkan kepercayaan dirinya melalui sumber belajar vicaroius leraning, yaitu belajar mengamati perilaku orang lain dengan setting bimbingan kelompok menggunakan media video edukasi.

Pelaksanaan kegiatan bantuan stimulasi dan intervensi yang diberikan kepada anak tuna grahita untuk meningkatkan efikasi dirinya melalui penggunaan media video edukasi dilakukan melalui 3 tahap yaitu:

1. Tahap 1. Penentuan jumlah siswa tunagrahita SLB Raharja Sejahtera Kandangan yang akan diberikan stimulasi untuk meningkatkan kemampuan efikasi dirinya dengan salah satu kriterianya yaitu siswa mampu diajak diskusi secara kelompok.

2. Tahap 2. Pelaksanaan

Setelah kelompok terbentuk, tahap berikutnya adalah pemberian stimulasi dengan menggunakan video edukasi untuk mengembangkan kemampuan efikasi diri siswa tuna grahita sesuai dengan proses yang diuraikan Bandura (Feist,2011) meliputi:

a. Proses kognitif, pada tahap ini setelah diberikan cuplikan video edukasi, siswa diajak menetapkan tujuan dan sasaran perilaku agar dapat merumuskan tindakan yang tepat dalam mencapai tujuan.

b. Proses motivasi, pada tahap ini siswa diajak untuk berpikiran optimis dalam mewujudkan tujuan yang diinginkan melalui umpan balik positif yang diberikan oleh fasilitator. Siswa diarahkan untuk memberikan keyakinan pada diri untuk tindakan yang akan dilakukan dan merencanakan tindakan yang akan direalisasikan.

c. Proses afeksi, pada tahap ini siswa diajarkan bagaimana mengontrol kecemasan dan perasaan depresif yang menghalangi pola-pola pikir yang benar dalam mencapai tujuan kemampuan yang diinginkan.

d. Proses seleksi, pada tahap ini siswa diajak untuk menyeleksi tingkah laku dan lingkungan yang tepat melalui diskusi singkat setelah pemberian cuplikan video edukasi.

3. Tahap 3. Evaluasi

Evaluasi dalam kegiatan ini dilakukan untuk mengukur ketercapaian dimensi efikasi diri anak tuna grahita meliputi :

a. Aspek level, yaitu mengukur seberapa besar tingkat keyakinan anak tuna grahita terhadap kemampuan yang dimiliki oleh dirinya terkait dengan tingkat kesulitan tugas.

b. Aspek generality, yaitu mengukur sejauh mana keyakinan anak tuna grahita terhadap kemampuan yang dimiliki berdasarkan tingkat keluasan tuga.

c. Aspek strength, yaitu mengukur sejauh manakah tingkat keyakinan anak tuna grahita terhadap kemampuan yang dimilikinya terkait dengan kemantapan hati dalam melakukan tuga-tugas yang harus diselesaikan. 
Sedangkan untuk data diperoleh dari hasil observasi, wawancara dan dokumentasi selama pemberian bantuan dan stimulasi dilakukan.

\section{HASIL DAN PEMBAHASAN}

Pemberian stimulasi serta intervensi pada anak tuna grahita dengan menggunakan video edukasi berhasil meningkatkan dimensi aspek efikasi dirinya, dikarenakan adanya umpan balik positif terhadap keterampilan yang mereka coba. Keterbatasan yang dimiliki oleh anak tuna grahita meliputi perkembangan inteligensi, interaksi sosial, penguasaan bahasa, dan kurang mampu untuk mempertimbangkan sesuatu yang menjadikannya sangat bergantung dengan orang tua atau orang dewasa lainnya.

Kondisi ketergantungan ini mendakan tingkat efikasi yang dimiliki anak tuna grahita perlu untuk ditingkatkan melalui pemberian stimulus dan intervensi dengan bantuan media yang menyajikan informasi menarik, menyenangkan, mudah dimengerti, jelas dan ada umpan balik positifnya berupa media video edukasi. Penggunaan media video edukasi diharapkan mampu mengoptimalkan kemampuan efikasi yang dimiliki anak tuna grahita karena ketika seseorang anak mengalami ketunagrahitaan membutuhkan pembelajaran yang bersifat konkret dan ada contoh yang diamati.

Bantuan intervensi dan stimulasi yang diberikan melalui setting bimbingan kelompok dengan bantuan media video edukasi dapat meningkatkan aspek efikasi diri anak tuna grahita meliputi:

a. Persepsi anak tuna grahita akan kemampuan dirinya. Aspek ini menjabarkan mengenai pandangan anak tuna grahita akan kemampuan dirinya dalam mengikuti pembelajaran dan mengerjakan tugas-tugas yang dimiliki.

b. Kesiapan anak tuna grahita dalam mengikuti pembelajaran. Aspek ini mengulas sejauh mana anak tuna grahita mampu mempersiapkan semua keperluannya mulai dari suasana hati sampai peralatan yang dibutuhkan dalam mengerjakan suatu hal.

c. Sikap atau reaksi terhadap hal baru. Aspek ini menggambarkan seberapa besar kemampuan anak tuna grahita dalam membaur dan memberikan reaksi terhadap lingkungan dan hal baru yang akan menjadi modal pengembangan potensinya.

d. Penguasaan keterampilan. Pada aspek ini dapat diamati bagaimana anak tuna grahita dapat mengatasi kesulitan-kesulitan yang ditemui.

e. Ketekunan usaha dan kerja keras yang dimiliki anak tuna grahita dalam menjalankan tugasnya.

Aspek efikasi diri anak tuna grahita ini dikembangkan melalui setting bimbingan kelompok merupakan suatu wujud media modifikasi perilaku yang dirancang untuk meningkatkan perilaku yang diinginkan dan pengurangan perilaku yang tidak diinginkan dengan menggunakan setting kelompok. Individu dibantu meningkatkan self efficacynya dengan memanfaatkan dinamika kelompok untuk mencapai tujuan tertentu yang berguna bagi kehidupan individu. 
Unsur penting yang harus ada adalah dinamika kelompok, seperti yang dikatakan oleh Prayitno (2017) bahwa bimbingan kelompok adalah suatu kegiatan yang dilakukan oleh sekelompok orang dengan memanfaatkan dinamika kelompok. Bimbingan kelompok merupakan layanan bimbingan dan konseling yang memungkinkan siswa secara bersama-sama melalui dinamika kelompok memperoleh berbagai bahan dari narasumber tertentu (terutama pembimbing) dan membahas secara bersama-sama pokok bahasan tertentu yang berguna untuk menunjang pemahaman dalam kehidupan sehari-hari dan untuk perkembangan dirinya baik sebagai individu maupun sebagai pelajar, dan untuk pertimbangan dalam pengambilan keputusan atau tindakan tertentu (Sukardi \& Nila,2008).

Perkembangan aspek kemampuan efikasi diri anak tuna grahita melalui pemberian stimulasi dengan menggunakan video edukasi ini lebih efektif karena media ini dapat didengar dan dilihat untuk menyajikan informasi dalam bentuk yang menyenangkan, menarik, mudah dimengerti dan jelas. Empat fungsi media pembelajaran khususnya media visual meliputi (Kustandi \& Bambang,2011):

a. Fungsi atensi, yaitu menarik dan mengarahkan perhatian anak tuna graahita untuk berkonsentrasi pada informasi yang disampaikan.

b. Fungsi afektif, yaitu dilihat dari tingkat kenikmatan anak tuna grahita ketika mendengarkan informasi melalui media.

c. Fungsi kognitif, terlihat dari pemahaman anak tuna grahita dalam mengingat informasi melalui tahap visual.

d. Fungsi kompensatoris untuk mengakomodasi anak tuna grahita yang lemah dan lamban dalam menerima serta memahami isi infomrasi yang disampaikan secara verbal.

\section{SIMPULAN}

Pemberian bantuan stimulasi dan intervensi melalui setting bimbingan kelompok dengan bantuan media video edukasi menunjukkan hasil meningkatnya keyakinan pada diri anak tuna grahita dalam menyelesaikan tugas sesuai target dengan pilihan perilaku yang diambil, meskipun banyak mengalami kesulitan dan tantangan.

Selain hal tersebut bentuk tujuan personal atau target yang ditentukan untuk mengukur tingkat perkembangan kemampuan efikasi anak tuna grahaita juga dipengaruhi oleh penilaian akan kemampuan diri. Semakin seseorang mempersepsikan dirinya mampu maka individu tersebut akan semakin termotivasi untuk membentuk usaha-usaha dalam mencapai tujuannya dan semakin kuat komitmen yang dibangun individu untuk mencapai tujuannya. Metode bimbingan kelompok bukanlah satu-satunya metode untuk merubah tingkah laku seseorang. Masih ada beberapa metode yang lain yang dapat digunakan untuk memodifikasi tingkah laku atau mengembangkan tingkah laku positif sebelumnya yang sudah dimiliki individu. 
Dengan meningkatnya self-efficacy anak tuna grahita diharapkan anak-anak mampu memiliki usaha yang gigih, rajin, ulet, dan tekun. Anak-anak mampu memiliki target untuk mendapatkan nilai yang maksimal, mempunyai rasa ingin tahu lebih besar terhadap hal yang diajarkan oleh guru pembimbing, aktif bertanya saat kegiatan bersama-sama di sekolah, memiliki semangat membaca untuk menambah wawasan, ketika menghadapi tugas-tugas atau pekerjaan yang sulit tidak mudah putus asa, dan menganggap kegagalan sebagai motivasi untuk lebih baik.

\section{UCAPAN TERIMAKASIH}

Kami haturkan terimakasih kepada Universitas PGRI Kanjuruhan yang telah mendukung dalam penyelesaian artikel ini.

\section{DAFTAR PUSTAKA}

ABKIN. (2007). Penataan Pendidikan Profesional Konselor dan Layanan Bimbingan dan Konseling dalam Jalur Pendidikan Formal. Depdiknas

Aldwin, C.M. (2007). Stress, Coping, And Development: An Integrative Perspective. Guilford Publications, Inc

Alwisol. (2009). Psikologi Kepribadian. UMM Press

Axford, K.M. (2007). Attachment, Affect Regulation, and Resilience in Undergraduate Students. Dissertation, Walden University, hlm. 64.

Bandura, A. (2002). Self-efficacy: In Changing Societies. Cambridge University Press

Baumrind, D. (2010). The influence of parenting style on adolescent competence and substance use. Journal of Early Adolescence, 11(1), 56-95

Bariyyah, K. (2013). Tingkat Self Efficacy Mahasiswa Bimbingan dan Konseling. Jurnal Konseling dan Pendidikan, 1(2).

Cormier L.S., Nurius, P.S., \& Osborn, C. J. (2012). Interviewing and Change Strategies for helpers (7th Ed). Boston: Brooks/Cole Cengange Learning

Sukardi, D.K, \& Nila, K. (2008). Proses Bimbingan dan Konseling di Sekolah. PT Rineka Cipta.

Efendi, M. (2006). Psikopedagogik Anak Berkelainan. Bumi Aksara.

Fauzan, L. (2009). Teknik Modeling. Diakses tanggal 17 September 2021 dengan alamat: http://lutfifauzan.wordpress.com/2009/12/23/teknik-modeling

Feist, \& Feist. (2011). Teori Kepribadian Jilid 2. Salemba Humanika.

Hudiyah, A.B.H. (2016). Efikasi Diri Anak Berkebutuhan Khusus yang Berprestasi di Bidang Olahraga. Jurnal Ilmiah Psikologi Terapan, 4 (2), 161-174

Kustandi, C., \& Bambang. S. (2011). Media Pembelajaran; Manual dan Digital. Ghalia Indonesia

Nursalim, M., dkk. (2005). Strategi Konseling. Unesa University Press

Pajares, C.T. (2002). Self-Efficacy Beliefs in Academic Setting. Review of Educational Research. Educational Research Covinal Research Bulletin

Prayitno. (2017). Konseling Profesional yang Berhasil: Layanan dan Kegiatan Pendukung. Rajawali Pers

Roberts, K., A. (2007). Self-Efficacy, Self-Concept, and Social Competence as Resources Supporting Resilience and Psychological Well-Being in Young Adults Reared within the Military Community. Dissertation, Fielding Graduate University, hlm. 18.

Santrock, J.W. (2002). Life Span Development :Perkembangan Masa Hidup Terjemahan. Erlangga 